\title{
DIAGNOSTIC OF COMPANY'S FINANCIAL CRISIS AS AN INSOLVENCY PREVENTION MEASURE
}

\author{
Iveta Mietule \\ Rezekne Academy of Technologies, Latvia \\ Alına Klodāne \\ Rezekne Academy of Technologies, Latvia
}

\begin{abstract}
Currently, the issues of insolvency and optimal financial situation of companies become increasingly topical. Simultaneously the company's crisis management with all its elements, including crisis diagnostics, have not been sufficiently studied yet. The object of the research is company's financial crisis diagnostics, the subject - methods of company's financial crisis diagnostics. The aim of the study - to carry out theoretical analysis of the company's financial crisis diagnostics in the view of insolvency prevention - is achieved applying monographic or descriptive research method, comparative analysis methods, as well as employing qualitative, grouping, and graphical methods.

As a result of the research, the authors have concluded that a status of company's insolvency, which can be characterized by the company's inability to perform its commitments and by predominance of the company's liabilities over its assets, is the last and the most severe stage of financial crises, mostly deriving from a long-term reluctance by the management to react to the current financial crisis in the company. Thus, one of the company's insolvency prevention options shall be timely detecting of symptoms of the company's financial crisis in its early stages - that is a priority objective of the crisis diagnostics. Crisis diagnostics is a systematic application of a several different (usually financial) models to assess the company's status and to identify possible symptoms of the crisis. Early detection of the crisis indications significantly increases possibilities of saving the company's assets.
\end{abstract}

Keywords: company crisis, crisis express-diagnostic method, crisis fundamental diagnostic method, insolvency.

JEL codes: H12; G01; G33; O16.

\section{Introduction}

Several Latvian authors have studied company's insolvency and related issues: R. Sneidere, 2007; I. Genriha and I. Voronova, 2005; E. Zelgalve, 2005; I. Berzkalne, 2016; K. Subatnieks, 2007; A. Auzina and A. Zvirbule-Berzina, 2009, etc. Insolvency and bankruptcy diagnostics issues are studied and commonly recognized business forecast models are developed by the following foreign researchers: E. Altman, 1968, L. A. Bernstein, 2000 (USA), R. Taffler, 1984 (UK), D. A. Botheras, 1979， J. G. Fulmer, 1984 (Canada), J. Mackevičius, 2008 (Lithuania), I. Blank, 2006 (Russia). Obviously, kind of a financial asymmetry as insolvency, firstly, is associated with its negative impact and negative (or even damaging) effects onto further company's financial development. This opinion is supported by a several of the above mentioned Latvian researchers, while, in the foreign researches, insolvency is characterised as a possible outcome of crisis (mostly unsolved) (Sabelfeld, Shavandina, 2006), and is considered as the last stage of the crisis situation development, thus allowing to argue that it is possible to prevent insolvency and to avoid large financial losses by diagnosing the company's crisis in its first stage of development, because, in that case, the possibilities to prevent further development of crisis increase. In this context, the necessity of early detection of the symptoms, forecasting of crisis situations, and assessment of probability 
of the crisis becomes crucial, indicating the main tasks of the crisis diagnostics. Though a number of researchers and economists in their studies (Sakalas and Virbickaite, 2011; Garskaite-Milvydiene, 2014; Meiste and Jakstiene, 2015; Darling and Kash, 1998; Blank, 2006; Asaul et al., 2007; Korotkov, 2010) reiterate the benefits of systematic implementation of efficient crisis diagnostics for the needs of the company's management, still the crisis diagnostics and prediction issues as well as anti-crisis management issues remain barely studied in the economic and management science both in Latvia and abroad.

The goal of the research is to carry out theoretical analysis of the company's financial crisis diagnostics in terms of insolvency prevention. To achieve the aim the following tasks are set:

1. To explore the theoretical studies related to the issue of the research;

2. To carry out comparative analysis of the company's financial crisis diagnostic methods;

3. To explore the company's financial crisis diagnostics as an insolvency prevention measure.

Object of the research is the company's financial crisis diagnostics, subject - methods of company's financial crisis diagnostics.

Monographic or descriptive research method, comparative analysis methods, as well as qualitative, grouping, and graphical methods were used to achieve the aim of the research. The above mentioned methods were used to analyse a sample of related theoretical material.

\section{Insolvency aspect}

Company's financial situation and solvency is an up-to-date issue among Latvian researchers and economists. Increasingly, there is a debate on various aspects of related challenging issues. In the scientific field, new ideas, researches on issues of the company's solvency, financial status, and possibilities of its assessment are offered continuously. Insolvency and related issues are studied by Latvian researchers R. Sneidere, I. Genriha and I. Voronova; E. Zelgalve; V. Paupa etc. (Šneidere, 2007; Genriha and Voronova, 2010; Zelgalve, 2005). I. Berzkalne (Berzkalne, 2016) has analysed the impact of the structure of assets of Latvian companies onto results of the company's performance, K. Subatnieks (Subatnieks, 2007) has carried out research on possibilities to use a cash-flow data in financial analysis. A. Auzina and A. Zvirbule-Berzina in their research (Auzina and Zvirbule-Berzina, 2009) analyse the relation between the external factors initiating financial crises and the company's solvency. Some of the researchers have published educational materials providing summary of traditional financial analysis methods to assess financial situation and results of business performance (Sneidere, 2007). Recognisably, the foreign researchers have paid a lot of attention studying insolvency issues. The following internationally recognized foreign researchers have studied insolvency and bankruptcy diagnostics issues, as well as have developed currently recognized business forecast models: E. Altman, 1968, L.A. Bernstein, 2000 (USA), R. Taffler, 1984 (UK), D.A. Botheras, 1979, J.G. Fulmer, 1984 (Canada), J. Mackevičius, 2008 (Lithuania). Current Lithuanian researchers A. Dziekevičius and B. Jonatiene in their study (Dziekevičius and Jonatiene, 2015) have carried out analysis of the most appropriate financial indicators that could be used to characterise operation of the Lithuanian companies in different sectors. The researches by these and other authors (Mackevičius, 2008; Garskaite-Milvydiene, 2012; Berzkalne, 2016) demonstrate that issues of the company's insolvency, financial status, potential and their assessment possibilities are upto-date issues nowadays.

The theory offers a number of opinions related to the definition of the concept of insolvency based on the studies developed by the researchers from a number of different countries with 
different economic systems. Nevertheless, R. Šneidere concludes that definitions of the term provided in the literature and legislative acts define company's insolvency as financial conditions of the company, when it (company) cannot carry out payments for its liabilities in prompt time (Šneidere, 2007). In other words, the situation in the company can be described as a financial asymmetry, when the company's liabilities are larger than its assets. Clearly, this situation is primarily associated with a negative impact and negative (or even subversive) effects on the company's further financial development. Several researchers, first and foremost, emphasize that the company's insolvency has a negative impact, and it is undesirable both for an individual business entity (company), and national economy in general (Rosenblatt, 1989; Sharma and Mahajan, 1980; Genriha and Voronova, 2010; Zelgalve, 2005; Sakalas and Virbickaite, 2011). This definition is supported by several Latvian researchers mentioned in this paper. In turn, some of the foreign researchers consider that insolvency is a possible outcome of the company's crisis (mostly unsolved) (Sabelfeld, Shavandina, 2006, Meiste and Jakstiene, 2015) and the last stage of the crisis development, and therefore has to be positioned as an alternative rather than an inevitable solution of the company's financial crisis. It is emphasized: an essential disparity and failure to provide business with the financial resources can appear if adequate measures are not allocated to solve the crisis, and that situation would be defined as an insolvency or bankruptcy (Sabelfeld, Shavandina, 2006). Consequently, the company's financial crisis is closely connected to the concept of insolvency.

In period of economic stability, crisis is often considered as a negative phenomenon (Rosenblatt, 1989), and its development is related to certain changes. It is noticed that there is a strong link between the crisis and the changes, i.e., impulses of positively solved crisis will be reflected in successful company's development (Sakalas and Virbickaite, 2011; Meiste and Jakstiene, 2015). Lithuanian researchers A. Sakalas and R. Virbickaite (Sakalas and Virbickaite, 2011) conclude that some researchers emphasise a positive impact of crisis onto the company's further economic development if the crisis situation diagnostics is carried out at its first stage. K. Garskaite-Milvydiene (Garskaite-Milvydiene, 2014) sustains that a consistent enterprise bankruptcy threat diagnostic system is required that would make it possible to comprehensively assess the enterprise's financial condition, as, if indications of crisis situation are identified at its early stages, the company has a possibility to react quickly and to diminish threats of crisis development. Diagnostics of the company's crisis in its first stage of development provides the company possibilities of overcoming the crisis further development, thus preventing insolvency and avoiding significant financial losses. In this context, the necessity of an early detection of the crisis symptoms, forecasting crisis development, and assessment of the crisis probability becomes crucial. All of the above mentioned are basic tasks of crisis diagnostics - a discipline of the anti-crisis management.

\section{Company's financial crisis diagnostics}

Although a number of researchers and economists in their works (Sakalas and Virbickaite, 2011; Garskaite-Milvydiene, 2014; Meiste and Jakstiene, 2015; Darling and Kash, 1998; Blank, 2006; Asaul et al., 2007; Korotkov, 2010) reiterate benefits that derive from systematic implementation of proficient crisis diagnostics for the needs of company's management, the crisis diagnostics and forecasting issues are still scarcely studied topics of anti-crisis management in the economics and management science both in Latvia and abroad. At the same time, the interest about the techniques and methodologies of crisis early detection and forecasting increases globally, thus complementing a range of existing teachings on the insolvency forecasting. 
In the current researches, the company's crisis diagnostics is defined as a systematic use of different (mostly financial) models assessing the company's financial conditions, as well as detecting any indications of the crisis (Sakalas and Virbickaite, 2011; Garskaite-Milvydiene, 2014; Meiste and Jakstiene, 2015; Sabelfeld, Shavandina, 2006). It is considered as a separate anti-crisis management function, a specific stage (Bajmahambetova, 2010). Crisis diagnostics becomes of a particular importance both for the anti-crisis management, and for the classical management systems, as it has a multi-benefit basis. For example, it provides:

- additional test of quality of financial reports;

- reliable information on the real situation and resources;

- reasonable basis for management decision making;

- timely identification of indications of crisis - possibility to save company's resources;

- basis for crisis forecasting and modelling;

- basis for development of a crisis management plan, etc.

The purpose of crisis diagnostics is timely identification of the crisis indications or explanation of the current crisis characteristics. As for the financial crisis diagnostics, several researchers (Sakalas and Virbickaite, 2011; Asaul et al., 2007; Blank, 2006) refer to the targeted financial analysis system, which is focused on detection of the company's crisis development and possible tendencies. Based on Ginevicius, Aleksandrov, and Dallas (Ginevicius et al., 2005; Aleksandrov, 2010; Dallas, 2012), K. Garskaite-Milvydiene states that "an enterprise bankruptcy threat diagnostic system is a retrospective, present-day oriented and prospective study of an enterprise's activities that consists of the assessment of the enterprise's financial condition. Based on the assessment, critical factors of the enterprise's activities determining the enterprise's crisis or bankruptcy, as well as the extent of the enterprise's crisis and possibilities of overcoming the crisis of the enterprise are identified" (Garskaite-Milvydiene, 2014). According implementing methods (Blank, 2006; GarskaiteMilvydiene, 2014) and general purposes (Kopitov and Dubko, 2009; Asaul et al., 2007), financial crisis diagnostics can be subdivided in two basic systems (See Fig. 1):

- crisis express diagnostic system, and

- crisis fundamental diagnostic system.

Some contemporary researchers, who have developed current diagnostic methods, do not position provided methods neither as express, nor fundamental ones. For example, Sakalas and Virbickaite (2011) propose to use artificial neural networks allowing overall assessment of the depth of company's crisis and dynamics of crisis development in the near future. 


\begin{tabular}{|c|c|}
\hline \multicolumn{2}{|c|}{ Company crisis management system } \\
\hline \multicolumn{2}{|c|}{ System of methods for the company's crisis diagnostics } \\
\hline Express methods & Fundamental methods \\
\hline Preventive analysis & Final analysis \\
\hline Structural analys is & Detailed analys is \\
\hline $\begin{array}{l}\text { Detection of crisis symptoms and } \\
\text { provisional as sess ment of situation }\end{array}$ & Assessment of crisis indications \\
\hline 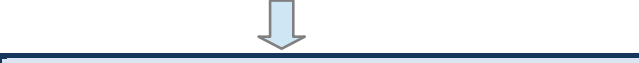 & 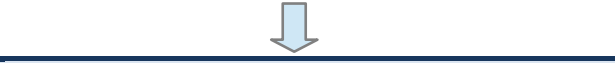 \\
\hline Crisis express diagnostics & Crisis fundamental diagnostics \\
\hline $\begin{array}{c}\text { System for regular evaluation of } \\
\text { characteristics of the company's financial } \\
\text { crisis development, implemented according } \\
\text { data of financial reports applying standard } \\
\text { analysis algorithms }\end{array}$ & $\begin{array}{l}\text { System for evaluation of characteristics of } \\
\text { the company's financial crisis } \\
\text { development, implemented on the bas is of } \\
\text { factor analysis and forecasting }\end{array}$ \\
\hline
\end{tabular}

Figure 1. Methods of the company's crisis diagnostics by purposes, implementing methods, and depth of study.

(Source: by the authors, based on Kopitov and Dubko, 2009; Asaul et al., 2007; Tung,1993; Garskaite-Milvydiene, 2014)

Crisis express diagnostics. Crisis express diagnostic method allows to identify the crisis symptoms in the company without in-depth analysis of the company's financial and economic performance indicators, providing possibility to detect 'bottlenecks' in the company's management system and to indicate directions of further analysis (Asaul et al., 2007), which in its turn is provided by fundamental diagnostics. Purposes of the express-diagnostics are evaluation of the overall company's financial situation, preparation of a forecast of the possible occurrence of the crisis in short time, or detecting depth or severity of the current crisis (determination of the extent of crisis). However, it has to be noted that results of this diagnostics and decisions based on these results mostly are provisional, and the conclusions have a nature of probability.

The analysis of literature (Kopitov and Dubko, 2009; Forsberg, 2012; Asaul et al., 2007; Tung, 1993; Blank, 2006; Korotkov, 2010; Garskaite-Milvydiene, 2014) demonstrates that process of express diagnostics is not complicated, and, as a rule, consists of four basic stages (see Fig. 2).

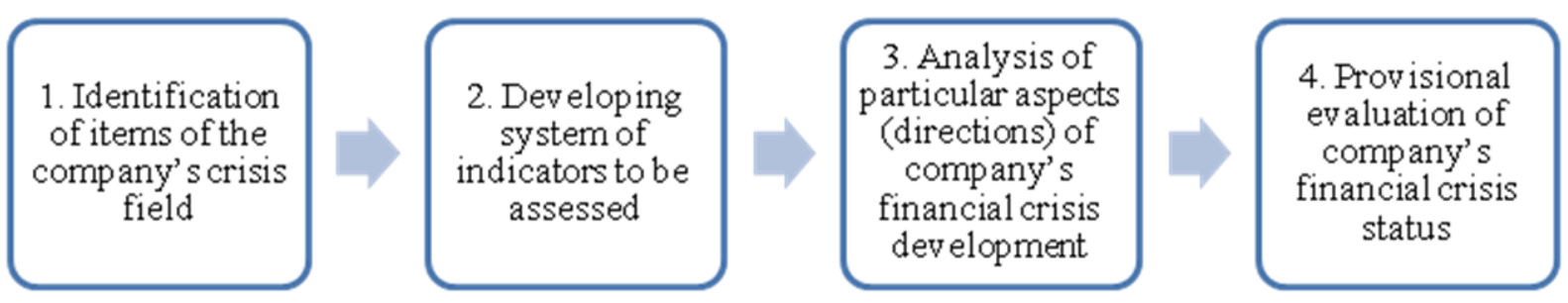

Figure 2. Basic stages of express diagnostics of the company's financial crisis.

(Source: by the authors based on Kopitov and Dubko, 2009; Forsberg, 2012; Asaul et al., 2007; Tung, 1993; Blank, 2006; Garskaite-Milvydiene, 2014) 
The company's financial crisis can occur within any of the company's business processes and because of a wide range of causes. The express diagnostic process starts with a selection of the items in the company's crisis field, which, by their nature, are the company's 'weak spots' that are most sensitive to the changes and reflect the probability of crisis occurrence. In the second stage, taking into account the selected crisis field items, an indicator system including characteristics of the field items is developed. The express-diagnostic ends with the fourth stage, or the provisional assessment of the company's financial crisis, which is carried out taking into account the results of analysis of particular aspects of the company's financial crisis performed at the third stage.

Company's crisis express diagnostic methods may vary depending on the specific system of objectives, the company's specifics, the items included in the field of crisis etc. Crisis express diagnostic system ensures early detection of the company's crisis development indications, enabling an effective implementation of crisis neutralization measures. Preventive effect of the crisis express diagnostics is particularly evident on the stage of mild financial crisis, while finding the financial crisis of a wider extent, the diagnostic must be accompanied by the fundamental crisis diagnostic system (Blank, 2006; Garskaite-Milvydiene, 2014), which provides a more in-depth and comprehensive explanation of the company's financial crisis.

Crisis fundamental diagnostics. The fundamental crisis diagnostic method differs from express-diagnostic as it is more in-depth and analytically comprehensive. Fundamental crisis diagnostics is characterised by a number of researchers as a system designed for evaluation of characteristics of the company's financial crisis, which is implemented on the basis of factor analysis and forecasting (Garskaite-Milvydiene 2014; Kopitov and Dubko, 2009; Blank, 2006; Asaul et al., 2007). This kind of in-depth diagnosis is mainly carried out when in the result of express-diagnostic the company's deep financial crisis or financial disaster is identified (Garskaite-Milvydiene, 2014), thus the results obtained by the fundamental diagnostic method complement (or expand) and confirm the assessment of the company's financial situation carried out during the previous diagnostic. The main tasks of the fundamental financial crisis diagnostics are defined by foreign researchers (GarskaiteMilvydiene 2014; Blank, 2006; Asaul et al., 2007):

- to review and to carry out an in-depth evaluation of the characteristics obtained during the express-diagnostic of the company's financial crisis;

- to justify and to approve provisional assessment of the extent of the company's financial crisis;

- to forecast nature of development and negative effects of the individual factors generating threats of the company's financial crisis;

- to assess and predict the company's ability to prevent (neutralize) financial crisis using its internal financial potential.

Defined tasks have to be implemented in several stages, which, in accordance with the economists, have some differences. The Lithuanian researcher (Garskaite-Milvydiene, 2014) offers the following four stages:

1. Identification and examination of the key factors determining company's crisis development;

2. Identification of company's critical (crisis) condition and development of effective measures relevant to the extent of the crisis;

3. Selection of effective internal measures for the company's financial stabilisation relevant to the extent of crisis;

4. Selection of efficient forms of restructuration. 
Several Russian researchers (Asaul et al., 2007; Blank, 2006) describe five basic stages of the fundamental crisis diagnostic process (see Fig. 3).
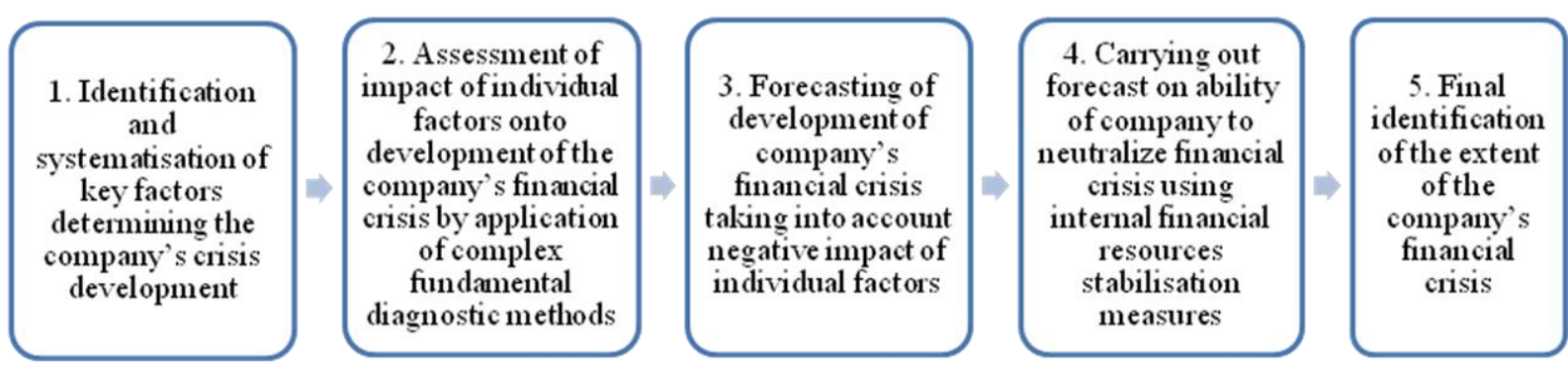

Figure 3. Basic stages of fundamental diagnostics of the company's financial crisis (Source: by authors based on Asaul et al., 2007; Blank, 2006)

Comparative analysis leads to the conclusion that the Russian researchers are more detailed subdividing the crisis' fundamental diagnostic process, distinctly emphasising a need to set up a system of basic factors determining development of the company's financial crisis, as well as identifying a stage for forecasting the company's financial crisis development taking into account the negative impact of individual factors (Stage 1 and Stage 3 respectively, Fig. 3). Though, the Lithuanian researcher combines identification of the key factors and assessment of their impact in the first stage, and considers the forecast as a necessary reaction measure. K. Garskaite-Milvydiene, at the same time, separates stage of selection of effective restructuring forms on the ground that the need for restructuring is assessed at the moment when the company's ability to implement internal financial stability measures is evaluated.

Overall, the fundamental diagnostics of the company's financial crisis allows to obtain more comprehensive explanation of the company's financial crisis and to specify possible methods and forms of financial recovery. The diagnostics of this kind without the results of expressdiagnostics (or instead of it) is not completely effective because, in the case of absence of real symptoms of crisis, the fundamental crisis diagnostics being implemented on systematic basis becomes a labour-intensive and capital intensive job, which may result in a superficial attitude towards the process by the staff and management directly involved.

To have an opportunity to prevent a potential crisis or to reduce negative effects caused by the crisis, any of the applied crisis diagnostic methods shall provide a forecast of potential crisis situations before it actually occurs and before the obvious indications of crisis appear. Timely, systematic, and comprehensive crisis diagnostics provides an opportunity to prevent the crisis before it intensifies, thus preventing insolvency (bankruptcy), and, in addition, making it possible to effectively manage the company's financial resources.

\section{Conclusions}

The study has led to the conclusion that the company's insolvency, which can be characterized as the company's inability to perform its commitments, and predominance of the company's liabilities over its assets, is the last and most severe stage of financial crisis development, mostly deriving from a long-term reluctance by the company's management to react to the obvious financial crisis.

If a real crisis is identified at its early stages, the company has a possibility to react quickly and to diminish threats of crisis development; in turn, prevention of the crisis further development, prevents insolvency risks avoiding significant financial losses. Thus, one of the possibilities to prevent the company's insolvency is a timely identification of symptoms of financial crisis at its early stages of development - that is a priority objective of crisis 
diagnostics. Crisis diagnostics is a systematic application of several different (mostlyfinancial) models to assess the company's situation and a detection of possible indications of crisis.

Express-diagnostics of the company's financial crisis, in a view of insolvency prevention, increases the company's ability to prevent occurrence of insolvency, providing an opportunity to quickly recognise upcoming financial crisis or its milder symptoms. In turn, during the fundamental diagnostics, a probability of insolvency occurrence is forecasted and/or characterised in detail, obtaining in-depth and comprehensive characteristics of the most sever stages of financial crisis.

\section{References}

Altman, E. (1968). Financial ratios, Discriminant Analysis and the Prediction of Corporate Bankruptcy. Journal of Finance, vol.2, pp. 589-609.

Aleksandrov, G. A. (2010). Antikrizisnoe upravlenie: teorija, praktika, infrastruktura. Moskva.

Asaul, A. N., Korotaeva, J. V., Knjaz', I. P. (2007). Teorija i praktika prinjatija reshenij po vyhodu organizacij iz krizisa. SPb: ANO «IPEV».

Auzina, A., Zvirbule-Berzina, A. (2009). Uznemumu maksatnespejas izraisoso arejo faktoru analize Latvija. Economic Science for Rural Development, no. 18, , pp. 13-191.

Bajmahambetova, G. I. (2010). Diagnostika krizisa v antikrizisnom upravlenii. Vestnik $K a z N U$, № 5 (81), pp. 87-92.

Bernstein, L. (2000). Analysis of Financial Statement. New York: McGraw-Hill.

Berzkalne, I. (2016). Komercsabiedribu kapitala strukturas ietekme uz darbibas finansu rezultatiem. Doctoral Thesis. Riga: University of Latvia.

Blank, I. A. (2006). Antikrizisnoe finansovoe upravlenie predprijatiem. KIEV: El'ga.

Botheras, D. A. (1979). Use of a business failure prediction model for evaluating potential and existing credit risk. Simon Fraser University.

Dallas, L. (2012). Short-termism, the financial crisis, and corporate governance, Journal of Corporation Law, no. 37, pp. 264-361.

Darling, J. R., Kash, T. (1998). Crisis Management: Prevention, Diagnosis and Intervention. Leadership \& Organization Development Journal, vol. 19, pp.179-186.

Dziekevičius, A., Jonatiene, B. (2015). Searching for the best financial ratios evaluating companies operating in different Lithuanian sectors. Business: Theory and Practice, vol. 2015 16(2), pp. 174-184. Available at http://dx.doi.org/10.3846/btp.2015.533

Fosberg, R. H. (2012). Capital structure and the financial crisis, Journal of Finance and Accountancy, no. 11, pp. 46-55.

Fulmer, J. G. (1984). A Bankruptcy Classification Model for Small Firms. The Journal of Commercial Bank Lending, pp.25-37.

Garskaite-Milvydiene, K. (2014). Anti-crisis management of enterprises and possibilities of overcoming their critical condition, Journal of Entrepreneurship and Sustainability Issues 1 (4). pp.187-203. DOI: http://dx.doi.org/10.9770/jesi.2014.1.4(1)

Garskaite-Milvydiene, K. (2012). Diagnostics of bankruptcy threat to enterprises, Journal of Security and Sustainability Issues 1 (3), pp.197-203. 
Genriha, I., Voronova, I. (2010). Maksatnespejas noteiksanas modeli Latvijas uznemumiem. Ekonomiskie petijumi uznemejdarbiba, No. 8, pp. 38-50.

Ginevicius, R., Bivainis, J., Melnikas, B., Paliulis, N., Rutkauskas, A.V., Staskevicius, A. J., Pabedinskaite, A., Seckute, L., Tamosiunas, A. (2005). Siuolaikinis verslas: tobulinimo prioritetai. Kolektyvinè monografija. Vilnius: Technika.

Kopitov, R., Dubko, N. (2009). The general conclusion of diagnosing models of shipping companies financial state for their functioning reliability. Proceedings of the 9th International Conference "Reliability and Statistics in Transportation and Communication", pp.45-54.

Korotkov, E. M., (2010). Antikrizisnoe upravlenie. Moskva: INFRA-M.

Mackevičius, J. (2008). Imonių veiklos analize - informacijos rinkimo, tyrimo ir vertinimo sistema. Informacijos mokslai, (46), pp. 46-56.

Meiste, R., Jakstiene, S. (2015). Crisis Diagnosis in Anti-Crisis Management Process in a Company. Institute of Economic Research Working Papers, no. 9/2015.

Rosenblatt, M. (1989). Asymptotic Normality, Strong Mixing and Spectral Density Estimates. The Annals of Probability, vol. 12 (4), pp.1167-1180.

Sabelfeld, T. V., Shavandina, O. A. (2006). Analiz podhodov i metodov diagnostiki krizisnogo sostojanija predprijatija. Polzunovskij vestnik, №3, pp.185-190.

Sakalas, A., Virbickaite, R. (2011). Construct of the Model of Crisis Situation Diagnosis in a Company. Engineering Economics, Vol. 22 (3), pp. 255-261.

Subatnieks, K. (2007). Naudas plusmas izmantosana uznemuma finansu analize. Promocijas darbs. Riga: Latvijas Universitate.

Šneidere, R. (2007). Finansu analizes metodes uznemuma maksatnespejas prognozesanai. Doctoral Thesis.

Sharma, S., Mahajan, V. (1980). Early warning indicators of business failure. Journal of Management, vol. 44, pp. 80-89.

Taffler, R. (1984). Empirical models for the monitoring of UK corporations. Journal of Banking and Finance, no. 8, pp.199-287.

Tung, B. (1993). Kachestvo upravlenija v uslovijah krizisa. Problemy teorii i praktiki upravlenija, № 1 .

Zelgalve, E. (2005). Maksatspejas jedziens finansu teorija. LU raksti, Ekonomika IV, Vol. 689, pp. 364-375. Available at http://www.lu.lv/materiali/apgads/raksti/689.pdf 